\title{
Direct Aziridination of Alkenes by a Cationic (Salen)ruthenium(VI) Nitrido Complex
}

\author{
Wai-Lun Man, ${ }^{\dagger}$ William W. Y. Lam, ${ }^{\dagger}$ Shek-Man Yiu, ${ }^{\dagger}$ Tai-Chu Lau, ${ }^{*}{ }^{\dagger}$ and Shie-Ming Peng ${ }^{\ddagger}$ \\ Department of Biology and Chemistry, City University of Hong Kong, Tat Che Avenue, Hong Kong, PRC, and \\ Department of Chemistry, National Taiwan University, Taipei 106, Taiwan, ROC
}

Received July 11, 2004; E-mail: bhtclau@cityu.edu.hk

The transfer of atoms or groups, multiply bonded to a transition metal, to an alkene is an important class of reactions. ${ }^{1}$ Although the transfer of oxygen atoms from metal-oxo species to alkenes to give epoxides ${ }^{2}$ and 1,2-diols ${ }^{3}$ as well as the transfer of carbenes from metal carbenes to give cyclopropanes ${ }^{4}$ have been extensively studied, less is known about the reactions of metal-nitrogen multiple bonds with alkenes. Nitrido complexes of manganese(V) porphyrin, ${ }^{5}$ manganese(V) salen, ${ }^{6}$ and ruthenium(VI) porphyrin ${ }^{7}$ have been used as reagents for the aziridination of alkenes; however, these complexes need to be activated with an electrophile such as trifluoroacetic anhydride to produce imido complexes as the active species. Although a wide variety of transition metal-nitrido complexes are known, none of them has been found to effect direct aziridination of alkenes. The cationic species cis-[(terpy)Os(N)$\left.\mathrm{Cl}_{2}\right]^{+}$reacts directly with aryl-substituted alkenes; however, unusual $\eta^{2}$-azaallenium complexes, in which the nitrogen atom inserts between the two carbons of the alkene, are formed rather than aziridines. ${ }^{8}$ This osmium complex also undergoes a $[4+1]$ cycloaddition reaction with cyclohexadienes to produce bicyclic osmium amido complexes. ${ }^{9}$

We recently reported the synthesis and reactivities of a highly electrophilic, cationic ruthenium(VI) nitrido complex containing the cyclohexylene-bridged salen ligand, $N, N^{\prime}$-bis(salicylidene) $o$-cyclohexyldiamine dianion (salchda). ${ }^{10}$ We report herein that this ruthenium(VI) nitrido species undergoes direct nitrogen atom transfer to alkenes at room temperature to produce (salen)ruthenium aziridine complexes.

No reaction occurs between $\left[\mathrm{Ru}^{\mathrm{VI}}(\mathrm{N})(\right.$ salchda $\left.)\left(\mathrm{CH}_{3} \mathrm{OH}\right)\right] \mathrm{PF}_{6}(\mathbf{1})$ (0.16 mmol) and 2,3-dimethyl-2-butene $(8.4 \mathrm{mmol})$ in $\mathrm{CH}_{2} \mathrm{Cl}_{2}(5$ $\mathrm{mL}$ ) for over $24 \mathrm{~h}$ at room temperature. However, upon addition of a nitrogen donor ligand $(2.5 \mathrm{mmol})$ such as pyridine (py) or 1-methylimidazole (1-MeIm), 1 reacts readily with 2,3-dimethyl2-butene to give a blue solution, which then gradually changes to green after ca. $3 \mathrm{~h}$ at room temperature. ${ }^{11}\left[\mathrm{Ru}^{\mathrm{IV}}\left(\mathrm{Az}^{1}{ }_{(-\mathrm{H})}\right)(\right.$ salchda)(py) $] \mathrm{PF}_{6}\left(\mathbf{2}, \mathrm{Az}^{1}=2,2,3,3 \text {-tetramethylaziridine }\right)^{12}$ and $\left[\mathrm{Ru}^{\mathrm{III}}\left(\mathrm{Az}^{1}\right)\right.$ (salchda)(py) $\mathrm{PF}_{6}(\mathbf{3})^{13}$ have been isolated from the blue and green solutions, respectively. ${ }^{14}$ Compound $\mathbf{2}$ is formulated as a $\mathrm{Ru}^{\mathrm{IV}}$ complex with a deprotonated aziridine ligand. The electrospray ionization mass spectrometry (ESI-MS) of $\mathbf{2}$ in $\mathrm{CH}_{2} \mathrm{Cl}_{2}$ (+ve mode) shows peaks at $m / z=599$ and 520 , which are assigned to the parent ion $\left[\mathrm{Ru}^{\mathrm{IV}}\left(\mathrm{Az}_{(-\mathrm{H})}{ }_{(-)}(\text {salchda })(\mathrm{py})\right]^{+}\right.$and $\left[\mathrm{Ru}^{\mathrm{IV}}\left(\mathrm{Az}_{(-\mathrm{H})}{ }\right)(\text { salchda })\right]^{+}$ respectively. 2 is diamagnetic, consistent with its formulation as a $d^{4} \mathrm{Ru}^{\mathrm{IV}}$ complex. ${ }^{10}$ Solutions of $\mathbf{2}$ in various solvents such as $\mathrm{ClCH}_{2^{-}}$ $\mathrm{CH}_{2} \mathrm{Cl}, \mathrm{CH}_{3} \mathrm{CN}$, or $\mathrm{CH}_{3} \mathrm{OH}$ are found to be converted to 3 within hours at room temperature.

Compound $\mathbf{3}$ has a room-temperature magnetic moment of $\mu_{\mathrm{eff}}$ $=1.99 \mu_{\mathrm{B}}$ (Gouy method), consistent with its formulation as a $d^{5}$ $\mathrm{Ru}^{\mathrm{III}}$ complex. The ESI-mass spectrum (+ve mode) of $\mathbf{3}$ in $\mathrm{CH}_{2}-$

\footnotetext{
City University of Hong Kong.

\$ National Taiwan University.
}

$\mathrm{Cl}_{2}$ shows a single peak at $m / z=600$, which is assigned to the parent ion $\left[\mathrm{Ru}^{\mathrm{III}}\left(\mathrm{Az}^{1}\right)(\text { salchda })(\mathrm{py})\right]^{+}$. The $\mathrm{N}-\mathrm{H}$ stretch of the aziridine, however, is not observed in the IR. The structure of $\mathbf{3}$ has been determined by X-ray crystallography (Figure 1). The $\mathrm{Ru}-$ $\mathrm{N}$ (aziridine) distance of 2.1049(19) $\AA$ is similar to the $\mathrm{Ru}-\mathrm{N}(\mathrm{py})$ distance of 2.1068(19) $\AA$, consistent with a neutral aziridine ligand. The $\mathrm{C}-\mathrm{C}(1.513 \AA)$ and $\mathrm{C}-\mathrm{N}(1.506,1.511 \AA)$ distances in the aziridine ligand are all indicative of single bonds. There are a few examples of aziridine complexes, including that of $\mathrm{Rh},{ }^{15} \mathrm{~W},{ }^{16} \mathrm{Mn},{ }^{16}$ and $\mathrm{Co},{ }^{17}$ these are all prepared by direct ligation of the aziridine to the metal center.

$\mathbf{1}$ also reacts at room temperature with a variety of aryl-substituted alkenes including styrene and trans- $\beta$-methylstyrene in the presence of py or 1-MeIm to give the corresponding ruthenium(III) aziridine complexes, which are air-stable dark-green crystalline solids. For these substrates, however, the orange solution of $\mathbf{1}$ is changed directly to green upon addition of the alkene without going through a blue intermediate. This suggests that the intermediate $\mathrm{Ru}^{\mathrm{IV}}\left(\mathrm{Az}_{(-\mathrm{H})}\right)$ species for these substrates are highly unstable and are reduced rapidly to the corresponding $\mathrm{Ru}^{\mathrm{III}}(\mathrm{Az})$ species. The structure of the complex obtained from trans- $\beta$-methylstyrene, $\left[\mathrm{Ru}^{\mathrm{III}}\left(\mathrm{Az}^{2}\right)(\right.$ salchda $\left.)(1-\mathrm{MeIm})\right] \mathrm{PF}_{6} \quad\left(\mathbf{4}, \mathrm{Az}^{2}=\right.$ trans-2-methyl-3phenylaziridine $),{ }^{18}$ has been determined by X-ray crystallography (Figure S1, Supporting Information). The aziridine ligand is in the trans configuration, indicating that no isomerization has occurred. The $\mathrm{Ru}-\mathrm{N}$ (aziridine) distance $(2.097 \AA)$ is similar to that in $\mathbf{3}$.

The free aziridines (Az) can be liberated in $90-95 \%$ yield (GC) from the ruthenium(III) aziridine complexes, $\left[\mathrm{Ru}^{\mathrm{III}}(\mathrm{Az})\right.$ (salchda)(L) $\mathrm{PF}_{6}(\mathrm{Az}=$ 2,2,3,3-tetramethylaziridine, 2-phenylaziridine or trans-2-methyl-3-phenylaziridine; $\mathrm{L}=$ py or 1-MeIm) by reduction of $\mathrm{Ru}$ (III) to $\mathrm{Ru}$ (II) with zinc amalgam in acetonitrile in the presence of 10 equiv of $\mathrm{PPh}_{3}$ (Supporting Information).

The kinetics of the reaction of $\mathbf{1}$ with 2,3-dimethyl-2-butene in the presence of pyridine under argon have been studied by UVvis spectrophotometric methods. The UV-vis spectral changes in 1,2-dichloroethane at $298.0 \mathrm{~K}$ show that this reaction consists of two well-separated consecutive steps (Figure S2). The final spectra for the first and second steps are very similar to those of $\mathbf{2}$ and $\mathbf{3}$, respectively; hence, the reaction scheme is $\mathbf{1} \rightarrow \mathbf{2} \rightarrow \mathbf{3}$. The kinetics of the first step were studied under pseudo-first-order conditions $\left(\left[\mathrm{Ru}^{\mathrm{VI}}\right]=1.0 \times 10^{-3}-1.0 \times 10^{-4} \mathrm{M}\right.$, [alkene $]=1.0-1.8 \mathrm{M}$, [py] $=0.02-1.0 \mathrm{M})$, the growth of 2 at $642 \mathrm{~nm}$ followed firstorder kinetics for over three half-lives. The pseudo-first-order rate constant, $k_{\mathrm{obs}}$, is independent of [ $\mathrm{Ru}^{\mathrm{VI}}$ ], depends linearly on [alkene], but exhibits saturation behavior on [py] (Figure S3). The rate law of the reaction is shown in eq 1 .

$$
\frac{-\mathrm{d}\left[\mathrm{Ru}^{\mathrm{VI}}(\mathrm{N})\right]}{\mathrm{d} t}=k_{2}\left[\mathrm{Ru}^{\mathrm{VI}}(\mathrm{N})\right][\text { alkene }]\left(\frac{K[\mathrm{py}]}{1+K[\mathrm{py}]}\right)
$$

The observed saturation kinetics on varying [py] is consistent with 


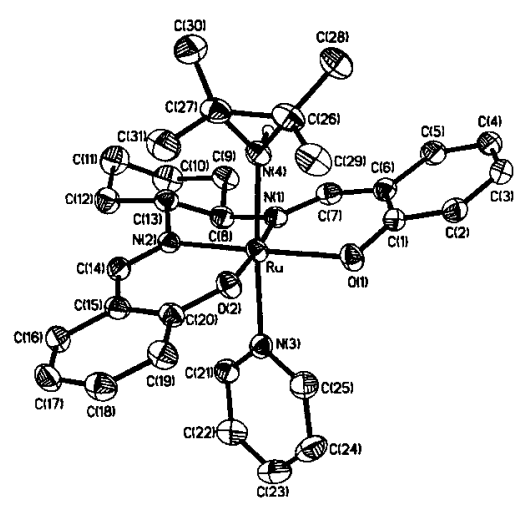

Figure 1. Molecular structure of the cation of $\mathbf{3}$, thermal ellipsoids drawn at the $30 \%$ probability ( $\mathrm{H}$ atoms are omitted except $\mathrm{N}(4)-\mathrm{H})$. Selected bond lengths ( $\AA$ ) and bond angles (deg): $\mathrm{Ru}-\mathrm{N}(4) 2.1049(19), \mathrm{Ru}-\mathrm{N}(3)$ 2.1068(19), $\mathrm{Ru}-\mathrm{N}(1) 2.009(2), \mathrm{Ru}-\mathrm{N}(2)$ 1.9844(19), $\mathrm{Ru}-\mathrm{O}(1) 2.0047(16)$, $\mathrm{Ru}-\mathrm{O}(2)$ 2.0098(16), $\mathrm{C}(26)-\mathrm{C}(27) 1.513(4), \mathrm{N}(4)-\mathrm{C}(26) 1.506(3), \mathrm{N}(4)-$ $\mathrm{C}(27)$ 1.511(3), N(3) $-\mathrm{Ru}-\mathrm{N}(4)$ 177.03(7), $\mathrm{Ru}-\mathrm{N}(4)-\mathrm{C}(26)$ 131.67(16), $\mathrm{Ru}-\mathrm{N}(4)-\mathrm{C}(27)$ 133.76(15), C(26)-N(4)-C(27) 60.21(16), N(4)-C(26)$\mathrm{C}(27)$ 60.04(15), N(4) $-\mathrm{C}(27)-\mathrm{C}(26) 59.75(15)$

Scheme 1

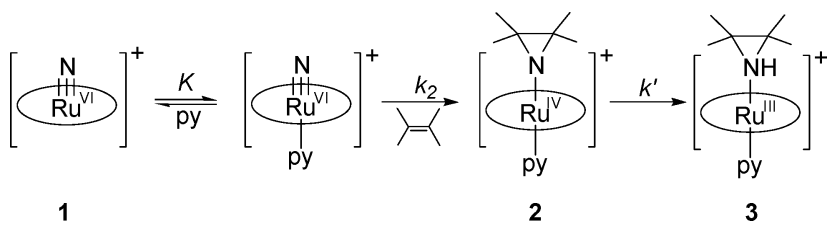

the reversible binding of pyridine to ruthenium(VI) (Scheme 1), and the equilibrium constant $K$ is $(15.6 \pm 1.1) \mathrm{M}^{-1}$ at $298.0 \mathrm{~K} . k_{2}$ (which represents the rate constant for the reaction between the pyridine-coordinated species, $\left[\mathrm{Ru}^{\mathrm{VI}}(\mathrm{N})(\text { salchda })(\mathrm{py})\right]^{+}$, and the alkene $)$ is found to be $(4.61 \pm 0.20) \times 10^{-3} \mathrm{M}^{-1} \mathrm{~s}^{-1}$ at $298.0 \mathrm{~K}$.

The second step of the reaction, i.e., $\mathbf{2} \rightarrow \mathbf{3}$, also follows firstorder kinetics for over three half-lives. The first-order rate constant, $k^{\prime}$, is independent of [ $\left.\mathrm{Ru}^{\mathrm{VI}}\right]$, [alkene] or [py]. At $298.0 \mathrm{~K}, k^{\prime}$ is found to be $(6.2 \pm 0.1) \times 10^{-4} \mathrm{~s}^{-1}$. The conversion of $\mathbf{2}$ to $\mathbf{3}$ was also independently studied using a pure sample of $\mathbf{2}$; the rate constants in 1,2-dichloroethane and acetonitrile were found to be $(9.0 \pm 0.3) \times 10^{-4}$ and $(8.2 \pm 0.3) \times 10^{-4} \mathrm{~s}^{-1}$, respectively, at $298.0 \mathrm{~K}$. The reaction of $\mathbf{1}$ with 2,3-dimethyl-2-butene can be represented by Scheme 1.

A similar ligand-accelerated reaction has also been observed in the epoxidation of alkenes by $\left[\mathrm{Cr}^{\mathrm{V}}(\operatorname{salen})(\mathrm{O})\right]^{+} .{ }^{19}$ In the five-coordinate complex the $\mathrm{Cr}$ atom is displaced $0.53 \AA$ above the salen plane; however, it is pulled back to $0.26 \AA$ upon axial ligation with pyridine $N$-oxide. This is accompanied by a weakening of the $\mathrm{Cr}=$ $\mathrm{O}$ bond. It is likely that similar geometrical changes occur upon coordination of pyridine to $\mathrm{Ru} \mathrm{VI} \equiv \mathrm{N}$, which would reduce the reorganization energy for atom transfer.

The conversion of $\mathrm{Ru}^{\mathrm{IV}}\left(\mathrm{Az}_{(-\mathrm{H})}\right)$ to $\mathrm{Ru}^{\mathrm{III}}(\mathrm{Az})$ species requires the addition of a $\mathrm{H}$ atom. In the reaction of $\mathbf{1}$ with excess styrene in py $/ \mathrm{CH}_{2} \mathrm{Cl}_{2}$, in addition to the formation of the corresponding ruthenium(III) aziridine complex, $\mathrm{PhC} \equiv \mathrm{N}$ was detected (GC) in the solution in $25 \%$ yield. ${ }^{20}$ Also a close examination of the UV/ vis spectral changes for $\mathbf{2} \rightarrow \mathbf{3}$ indicates that only $69 \pm 2 \%$ of $\mathbf{3}$ is formed. These observations are consistent with a mechanism that involves an initial rate-limiting, aziridine ring-opening rearrangement of $\mathrm{Ru}^{\mathrm{IV}}\left(\mathrm{Az}_{(-\mathrm{H})}\right)$ to a species $\mathbf{R u X}$ which can transfer $\mathrm{H}$ atoms to $\mathrm{Ru}^{\mathrm{IV}}\left(\mathrm{Az}_{(-\mathrm{H})}\right)$. When the substrate is styrene, loss of $\mathrm{H}$ atoms from $\mathbf{R u X}$ results in the formation of $\mathrm{PhC} \equiv \mathrm{N}$, among other products. A possible candidate for $\mathbf{R u X}$ is an $\eta^{2}$-azaallenium complex that is similar to that formed between $\left[(\text { terpy }) \mathrm{Os}(\mathrm{N}) \mathrm{Cl}_{2}\right]^{+}$and aryl- substituted alkenes, ${ }^{8}$ where the nitrogen atom of the aziridine is inserted between the carbon-carbon bond.

This is the first example of direct nitrogen atom transfer from a metal nitride to alkenes. The remarkable steric and electronic tunability of salen will be utilized to probe the mechanism of the aziridination reaction and the reduction of $\mathrm{Ru}^{\mathrm{IV}}\left(\mathrm{Az}_{(-\mathrm{H})}\right)$ to $\mathrm{Ru}^{\mathrm{III}}(\mathrm{Az})$.

Acknowledgment. The work described in this contribution was substantially supported by a grant from the Research Grants Council of Hong Kong (CityU 1117/00P), partially supported by the National Taiwan University.

Supporting Information Available: Experimental procedures and kinetics. X-ray crystallographic data (CIF). This material is available free of charge via the Internet at http://pubs.acs.org. See any current masthead page for ordering information and Web access instructions.

\section{References}

(1) (a) Nugent, W. A.; Mayer, J. M. Metal-Ligand Multiple Bonds; Wiley: New York, 1988. (b) Katsuki, T. In Comprehensive Coordination Chemistry II; Ward, M. D., Ed.; Elsevier: Oxford, 2004; Vol. 9, pp 207-264.

(2) (a) Strassner, T. Adv. Phys. Org. Chem. 2003, 38, 13-160. (b) Barf, G. A.; Sheldon, R. A. J. Mol. Catal. A: Chem. 1995, 102, 23-39. (c) Ostovic, D.; Bruice, T. C. Acc. Chem. Res. 1992, 25, 314-320

(3) (a) Schröeder, M. Chem. Rev. 1980, 80, 187-213. (b) Johnson, R. A.; Sharpless, K. B. In Catalytic Asymmetric Synthesis, 2nd ed.; Ojima, I., Ed.; Wiley-VCH: New York, 2000; Chapter 6.

(4) Brookhart, M.; Studabaker, W. B. Chem. Rev. 1987, 87, 411-432.

(5) Groves, J. T.; Takahashi, T. J. Am. Chem. Soc. 1983, 105, 2073-2074

(6) (a) Du Bois, J.; Tomooka, C. S.; Hong, J.; Carreira, E. M. Acc. Chem Res. 1997, 30, 364-372. (b) Minakata, S.; Ando, T.; Nishimura, M.; Ryu, I.; Komatsu, M. Angew. Chem., Int. Ed. 1998, 37, 3392-3394.

(7) Leung, S. K. Y.; Huang, J. S.; Liang, J. L.; Che, C. M.; Zhou, Z. Y. Angew. Chem., Int. Ed. 2003, 42, 340-343.

(8) (a) Brown, S. N. J. Am. Chem. Soc. 1999, 121, 9752-9753. (b) Maestri, A. G.; Taylor, S. D.; Schuck, S. M.; Brown, S. N. Organometallics 2004, 23, $1932-1946$

(9) Maestri, A. G.; Cherry, K. S.; Toboni, J. J.; Brown, S. N. J. Am. Chem. Soc. 2001, 123, 7459-7460.

(10) Man, W. L.; Tang, T. M.; Wong, T. W.; Lau, T. C.; Peng, S. M.; Wong, W. T. J. Am. Chem. Soc. 2004, 126, 478-479.

(11) Oxygen donor ligands such as DMSO and DMF can also induce the reaction of $\mathbf{1}$ with the alkene, but they are less effective.

(12) Preparation of 2: Pyridine $(0.2 \mathrm{~mL})$ was slowly added with stirring to an orange suspension of $\mathbf{1}(100 \mathrm{mg}, 0.16 \mathrm{mmol})$ in 2,3-dimethyl-2-butene (1 $\mathrm{mL}, 8.4 \mathrm{mmol})$ and $\mathrm{CH}_{2} \mathrm{Cl}_{2}(5 \mathrm{~mL})$ at room temperature. The resulting deep-blue solution was stirred for $5 \mathrm{~min}$. Addition of pentane gave a darkblue microcrystalline solid which was recrystallized from dichloromethane/ $n$-pentane at $-20{ }^{\circ} \mathrm{C}$. Yield: $50 \%$. Anal. Calcd. for $\mathrm{C}_{31} \mathrm{H}_{37} \mathrm{~N}_{4} \mathrm{O}_{2} \mathrm{PF}_{6} \mathrm{Ru}$ : C, 50.07: H, 5.01; N, 7.53. Found: C, 49.87; H, 5.20; N, 7.72. UV-vis $\left(\mathrm{Cl}_{2} \mathrm{CH}_{2} \mathrm{CH}_{2} \mathrm{Cl}_{2}\right): \lambda_{\max }[\mathrm{nm}]\left(\epsilon\left[\mathrm{mol}^{-1} \mathrm{dm}^{3} \mathrm{~cm}^{-1}\right]\right) 240(28840), 362$ $(11560), 660(2900) .{ }^{1} \mathrm{H}$ NMR $\left(300 \mathrm{MHz}, \mathrm{CD}_{3} \mathrm{CN}\right): \delta 8.8(\mathrm{~s}, 1 \mathrm{H}), 8.6(\mathrm{~s}$ $1 \mathrm{H}), 7.2-7.8(\mathrm{~m}, 9 \mathrm{H}), 6.8-7.0(\mathrm{~m}, 4 \mathrm{H}), 4.0-4.1(\mathrm{t}, 1 \mathrm{H}), 4.2-4.3(\mathrm{t}$, $1 \mathrm{H}), 3.2-3.2(\mathrm{~d}, 1 \mathrm{H}), 3.0-3.1(\mathrm{~d}, 1 \mathrm{H}), 0.93(\mathrm{~s}, 6 \mathrm{H})$ and $0.91(\mathrm{~s}, 6 \mathrm{H})$.

(13) Preparation of 3: The same procedure for the preparation of $\mathbf{2}$ was used except that the reaction time was $3 \mathrm{~h}$. The resulting green solution was filtered and concentrated to ca. $2 \mathrm{~mL}$. Addition of diethyl ether resulted in the precipitation of a green solid, which was dissolved in $\mathrm{CH}_{2} \mathrm{Cl}_{2}$ and loaded onto a silica gel column. Elution with $\mathrm{CH}_{2} \mathrm{Cl}_{2} /$ acetone $(30: 1)$ followed by recrystallization from $\mathrm{CH}_{2} \mathrm{Cl}_{2}$ /diethyl ether afforded $\mathbf{3}$ as darkgreen crystals. Yield: $50 \mathrm{mg}(41 \%)$. Anal. Calcd. for $\mathrm{C}_{31} \mathrm{H}_{38} \mathrm{~N}_{4} \mathrm{O}_{2} \mathrm{PF} 6 \mathrm{Ru}$ C, 50.00; H, 5.14; N, 7.52. Found: C, 49.84; H, 5.01; N, 7.69. UV-vis $\left(\mathrm{Cl}_{2} \mathrm{CH}_{2} \mathrm{CH}_{2} \mathrm{Cl}_{2}\right): \lambda_{\max }[\mathrm{nm}]\left(\epsilon\left[\mathrm{mol}^{-1} \mathrm{dm}^{3} \mathrm{~cm}^{-1}\right]\right) 239$ (30900), 378 (15300), 506 (1720), 712 (4480).

(14) Pyridine also induces $\mathrm{N}-\mathrm{N}$ coupling of $\mathbf{1}$. However, the reaction of 1 with the alkene is predominant when $[\mathrm{RuN}]<1 \mathrm{mM}$ and [alkene] $>1$ M.

(15) Lussier, R.; Edwards, J. O.; Eisenberg, R. Inorg. Chim. Acta 1969, 3, 468-470 and references therein.

(16) Lorenz, I. P.; Beckerath, S. V.; Nöth, H. Eur. J. Inorg. Chem. 1998, 645650.

(17) Ware, D. C.; Siim, B. G.; Robinson, K. G.; Denny, W. A.; Brothers, P. J.; Clark, G. R. Inorg. Chem. 1991, 30, 3750-3757.

(18) 4 was prepared by a procedure similar to that for 3 using trans- $\beta$ methylstyrene. Yield: (30\%). Anal. Calcd. for $\mathrm{C}_{33} \mathrm{H}_{37} \mathrm{~N}_{5} \mathrm{O}_{2} \mathrm{PF}_{6} \mathrm{Ru}$ : C, $50.70 ; \mathrm{H}, 4.77$; N, 8.96. Found: C, 49.97; H, 4.97; N, 9.05. ESI-MS in $\mathrm{CH}_{2} \mathrm{Cl}_{2}: m / z=636\left(\mathrm{M}^{+}\right)$

(19) Samsel, E. G.; Srinivasan, K.; Kochi, J. K. J. Am. Chem. Soc. 1985, 107, $7606-7617$.

(20) $\mathrm{PhC} \equiv \mathrm{N}$ was also observed when trans- $\beta$-methylstyrene was used as substrate. However, we have not been able to detect any organic products when 2,3-dimethyl-2-butene was used, presumably because the products could not be separated from other organics in the solution by GC.

JA045845F 